ISSN: 0213-2079 - ISSN electrónico: 2386-3889

DOI: http://dx.doi.org/10.14201/shhmo2016381193222

\title{
CAMBIADORES Y ELITES URBANAS: EL AUGE DE ANTONIO DE PAREDES Y SU FAMILIA EN VALLADOLID A INICIOS DEL SIGLO XVI"
}

\section{Moneychanging and Urban Elites: the Rise of Antonio de Paredes and his Family in Valladolid at the Beginning of the Sixteenth Century}

\author{
David CARVAJAL DE LA VEGA \\ Universidad de Valladolid \\ Correo-e: david.carvajal@eco.uva.es
}

RESUMEN: Desde finales del siglo xv, Valladolid atravesó un período de florecimiento que terminó por consolidar a «la villa del Esgueva» como uno de los centros neurálgicos de la Corona de Castilla durante el siglo XVI. En este contexto tan propicio para el desarrollo de los negocios comerciales y financieros, nuevos personajes y sus familias comenzaron a acrecentar su poder económico y a reforzar sus relaciones sociales, para terminar ocupando un lugar entre la sociedad urbana. El objetivo de este trabajo es trazar el camino seguido por el cambiador Antonio de Paredes a partir de su actividad financiera y de su creciente presencia entre las elites vallisoletanas. Una presencia que, junto a su capacidad económica y a su

* Este trabajo ha sido elaborado en el marco del proyecto de investigación Poder, sociedad y fiscalidad en la Meseta norte castellana en el tránsito del Medievo a la Modernidad, financiado por el Ministerio de Ciencia e Innovación, Plan Nacional de I+D+i (2008-2011) (HAR201127016-C02-02). Dicho proyecto forma parte de un Proyecto coordinado entre la Universidades de Valladolid y la Universidad del País Vasco Poder, sociedad y fiscalidad en la Corona de Castilla: un estudio comparado de la Meseta Norte y de la Cornisa Cantábrica en el tránsito del Medievo a la Modernidad (HAR2011-27016-C02) y está integrado en la red temática Arca Comunis (http:// arcacomunis.uma.es). Quiero expresar mi agradecimiento a D. Víctor Arenzana y a los profesores Irene Ruiz Albi y Mauricio Herrero Jiménez.

(C) Ediciones Universidad de Salamanca / ®@ Stud. his., H. ${ }^{a}$ mod., 38, n. 1 (2016), pp. 193-222 
DAVID CARVAJAL DE LA VEGA

CAMBIADORES Y ELITES URBANAS: EL AUGE DE ANTONIO DE PAREDES

Y SU FAMILIA EN VALLADOLID A INICIOS DEL SIGLO XVI

bien ganada reputación, acabaron por impulsar a sus hijos hasta formar parte del regimiento de la villa.

Palabras clave: cambiadores; negocios financieros; ascenso social; élites; Valladolid.

ABSTRACT: Since the late 15th century, Valladolid went through a period of prosperity that strengthened its position as one of the most significant towns in the Crown of Castile during the 16th century. This propitious context, favouring the development of commercial and financial businesses, prompted the appearance of individuals who, alongside their families, began to increase their economic power and to reinforce their social links, leading them to occupy a position among the urban elite. The aim of this paper is to trace the figure of Antonio de Paredes, a moneychanger, considering both his financial activities and his growing presence among Valladolid's urban elite. This greater presence, along with his economic status and his well-earned reputation, paved the road for his sons to become part of the town's local council.

Key words: Moneychangers; Financial Businesses; Social Climbing; Elites; Valladolid.

A fines del medievo, tanto la sociedad como la economía castellanas atravesaron por un período de fuerte dinamismo fácilmente apreciable en el desarrollo de las urbes y, especialmente, de aquellas que jugaban un papel relevante como centros políticos y mercantiles. En este contexto, es de sobra conocido el papel asumido por parte de los incipientes grupos mercantiles y financieros que encontraron en las ciudades castellanas el marco idóneo en el que prosperar económica y socialmente. Son numerosos los trabajos que han logrado plasmar esta tendencia de enriquecimiento y ascenso social en otros centros donde, a lo largo del siglo xv, varios mercaderes se incorporaron a un mundo escasamente conocido hasta entonces $^{1}$. De igual modo, aunque menos conocida, es notoria la creciente presencia de

1. El proceso de acceso a la oligarquía urbana en Burgos ha sido estudiado por GuerRero Navarrete, Y.: Organización y Gobierno en Burgos durante el reinado de Enrique IV de Castilla (1453-1476). Madrid, 1986, pp. 142-146; y Casado Alonso, H.: Señores, mercaderes y campesinos: la comarca de Burgos a fines de la Edad Media. Valladolid, 1987, p. 459. En el caso de ciudades como Cuenca o Bilbao, véase Jara Fuente, J. A.: Concejo, poder y élites. La clase dominante de Cuenca en el siglo XV. Madrid, 2001; y Pérez Hernández, S.: «Porque asy conbenia al bien de la dicha villa: cambios políticos en Bilbao (siglos XV-XVII)», en GARCíA Fernández, E.: Bilbao, Vitoria y San Sebastián: espacios para mercaderes, clérigos y gobernantes en el Medievo y la Modernidad.

(C) Ediciones Universidad de Salamanca / ®@ Stud. his., H. ${ }^{a}$ mod., 38, n. 1 (2016), pp. 193-222 
DAVID CARVAJAL DE LA VEGA

CAMBIADORES Y ELITES URBANAS: EL AUGE DE ANTONIO DE PAREDES

Y SU FAMILIA EN VALLADOLID A INICIOS DEL SIGLO XVI

financieros -arrendatarios de rentas, cambiadores...- entres las elites urbanas²; siendo este último un grupo que mantuvo una actividad intensa en núcleos como Jerez, Córdoba, Granada, Toledo, Segovia, Burgos o Valladolid ${ }^{3}$.

A lo largo del siglo xv algunos de los centros mencionados atravesaron por procesos de cambio en su estructura económica, social y política. Al menos en la meseta norte, el vigor de la actividad mercantil y financiera comenzaba a percibirse en ciudades, ferias y mercados, mientras el dinamismo social se hacía notar a través de la creciente movilidad de los agentes, de la presencia de foráneos y extranjeros llegados de Italia, Francia, Flandes o Portugal y, sobre todo, de la aparición de nuevos grupos interesados en prosperar socialmente, fijando su objetivo en el acceso a las elites y al gobierno urbano ${ }^{4}$. El ascenso al regimiento en centros como Burgos o Valladolid se convirtió en una meta para muchos sujetos que, aprovechando la apertura de los linajes y las posibilidades que les otorgaba su capacidad económica, buscaban formar parte de los grupos oligárquicos y consolidar su posición a través de la patrimonialización y transmisión del cargo ${ }^{5}$. Aunque esta tendencia puede rastrearse en otras urbes europeas a fines del siglo xv e inicios del xvi, donde el cambio económico y

Bilbao, 2005, pp. 257 y ss. En el caso de Valladolid es destacable la aportación de MArTín Romera, M. ${ }^{a}$ Á.: Las redes sociales de la oligarquía de la villa de Valladolid (1450-1520). Tesis doctoral, Universidad Complutense de Madrid, 2012, que se suma a los trabajos de Rucquor. A.: Valladolid en la Edad Media. El mundo abreviado. Valladolid, 1997; y, para el siglo XVI, Bennassar, B.: Valladolid en el Siglo de Oro. Valladolid, 1989.

2. CARlÉ, M. a del C.: «De cambios y cambiadores», Cuadernos de Historia de España, 76, 2000, pp. 121-138.

3. Los casos de Valladolid, Segovia o Burgos en, Carvajal de la Vega, D.: «En los precedentes de la banca castellana moderna: cambiadores al norte del Tajo a inicios del siglo XVI», en García Fernández, E. y Bonachía Hernando, J. A. (eds.): Hacienda, mercado y poder al norte de la Corona de Castilla en el tránsito del medievo a la modernidad. Valladolid, 2015, pp. 17-37. En los protocolos notariales de Granada podemos encontrar hasta 45 menciones a cambiadores, Obra Sierra, J. M. ${ }^{a}$ : Catálogo de protocolos notariales: Granada (1505-1515). Tesis Doctoral, Granada, 1986, p. 2406. Monguío Becher, F.: Antecedentes de la banca en Jerez de la Frontera. El Gremio de Cambiadores en la segunda mitad del siglo XV. Jerez de la Frontera, 1978.

4. Valga como ejemplo Francisco del Nero, corregidor de Segovia. Archivo Histórico Provincial de Valladolid [en adelante AHPV], Protocolos, c. 7838, fol. 360r-v.

5. Tomás y Valiente, F.: «Origen bajomedieval de la patrimonialización y la enajenación de oficios públicos en Castilla», en VV. AA.: Actas del I Symposium de Historia de la Administración. Madrid, 1970, pp. 123-159; Guerrero Navarrete, Y.: Organización y Gobierno en Burgos durante el reinado de Enrique IV de Castilla (1453-1476). Madrid, 1986, pp. 138-141; JARA FuenTE, J. A.: «Estructuras formales de poder y de organización de las clases dominantes urbanas en Castilla. El regimiento: una crisis del siglo XIV en el siglo XV», Edad Media. Revista de Historia, 8, 2007, pp. 225-241, en especial p. 240.

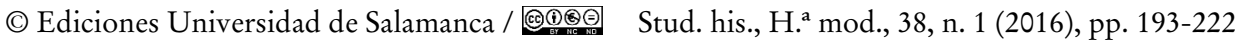


social fomentó la apertura de las elites, hay que tener en cuenta que los nuevos grupos en ascenso, asimilados a la «burguesía» o a «middle elite», varían mucho entre regiones, a pesar de compartir un patrón de valores coherente que definía su conducta y sus aspiraciones; una serie de características que diversos autores han expuesto a partir del ejemplo de los mercaderes castellanos ${ }^{6}$. En este trabajo queremos poner especial énfasis en otra de las vías de ascenso: las finanzas y, en particular, el cambio. A pesar de los riesgos asumidos por los cambiadores, nos interesa conocer si su negocio fue lo suficientemente sólido como para permitirles acceder a la elite urbana. Del mismo modo, es nuestra intención tratar otras estrategias de afianzamiento económico y social paralelas generadas a través de vínculos con aquellas familias que dominaban la vida económica y la sociedad vallisoletanas. Tal y como veremos, en el caso de Valladolid, el desarrollo de las finanzas y la especialización en torno al capital permitieron a un grupo de profesionales participar de la creciente movilidad social. Su actividad constituyó la plataforma necesaria para que diversos cambiadores y sus allegados estuviesen en disposición de participar en influyentes ámbitos de la vida urbana durante las primeras décadas del siglo xvi.

Dentro del marco de afianzamiento económico y social, y a partir de la evidencia documentada entre algunas familias de cambiadores, el presente texto pretende exponer la importancia del desarrollo de diversos negocios comerciales y financieros, y la utilidad de estos para lograr el ascenso social y económico en la villa, sin olvidar la reclamación que hace tiempo elevó E. Soria Mesa sobre la necesidad de incorporar el estudio de la genealogía familiar al análisis de las oligarquías urbanas en el mundo moderno ${ }^{7}$. Nuestro objetivo es profundizar en el estudio de los negocios financieros de Antonio de Paredes y de sus allegados, conocer los medios utilizados para incrementar su capacidad económica y, partiendo de la afirmación hecha por B. Bennassar, quien consideraba que el acceso a los linajes y a la élite urbana era fácil a inicios de siglo ${ }^{8}$, confirmar o no este principio a través de la experiencia de los cambiadores.

Son numerosos los ejemplos que permiten llevar a cabo un análisis de estas características. No obstante, nuestro interés por Antonio de Paredes deriva del estudio de un perfil de financiero que, durante varias décadas, desarrolló sus mejores dotes sociales y económicas en busca de la promoción social, mostrándose como un hábil agente capaz de asegurar la memoria de su familia en un entorno que, en

6. Kamen, H.: Early Modern European Society. Londres, 2000, pp. 95 y ss.

7. Soria Mesa, E.: «Los estudios sobre las oligarquías municipales en la Castilla moderna. Un balance en claroscuro», Manuscrits, 18, 2000, pp. 191 y ss.

8. Bennassar, B.: Valladolid en el Siglo de Oro. Valladolid, 1989, pp. 377-378.

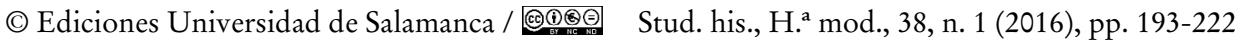


no pocas ocasiones, se mostró hostil hacia él y los suyos. En este sentido, cabe remarcar la pertinencia de este trabajo que permite trazar el proceso de ascenso de una familia foránea que llegó a ocupar varios puestos en uno de los regimientos más importantes de Castilla y que culminó en la incorporación a uno de los dos linajes vallisoletanos ${ }^{9}$, mostrando mayor flexibilidad que la planteada en algunos estudios sobre la realidad vallisoletana ${ }^{10}$.

La consecución de los objetivos de este trabajo viene marcada por una clara limitación de las fuentes disponibles. El hecho de no contar apenas con protocolos notariales vallisoletanos durante las dos primeras décadas del siglo xvi, nos ha llevado a realizar este estudio partiendo de testimonios notariales procedentes de centros donde muchos de los cambiadores analizados ejercieron sus actividades financieras -Medina del Campo, por ejemplo-, de documentación judicial -pleitos y reales ejecutorias-, procedente del Archivo de la Real Chancillería de Valladolid, amén de otra documentación local, como los libros de actas conservados hasta $1520^{11}$. Más allá de la mera acumulación de datos, la riqueza de la información obtenida nos permite cumplir de manera considerable con los fines propuestos.

\section{LA CONSOLIDACIÓN DE LOS CAMBIADORES EN LA MESETA NORTE CASTELLANA}

A fines del siglo xv el auge comercial y financiero de los grandes núcleos de la meseta norte castellana era a todas luces notable. Son muchas las evidencias que nos permiten comprobar un inusitado crecimiento económico y financiero de numerosas urbes al norte del Tajo: la actividad productiva de centros como Segovia, Palencia o Cuenca, el incremento del comercio exterior impulsado por mercaderes y consulados, el impulso económico propiciado por los mercados y las ferias o el desarrollo de la fiscalidad ${ }^{12}$. En este contexto tan propicio, la presencia de cambiadores se hizo cada vez más necesaria por ser estos los más capacitados para aportar crédito y liquidez a un sistema que demandaba recursos más allá de

9. Ibidem. Sobre el ejercicio del poder y la vinculación entre linaje y regimiento son interesantes las reflexiones de Jara Fuente, J. A.: Concejo, poder y élites. La clase dominante de Cuenca en el siglo XV. Madrid, 2001, pp. 397-398. No obstante, como se verá en el trabajo, resulta complicado conocer a fondo la relación de los Paredes dentro del sistema de linajes vallisoletano.

10. Gutiérrez Alonso, A.: «Sociedad y poder. La oligarquía vallisoletana y sus relaciones con otras instancias de poder» en VV. AA.: Valladolid. Historia de una ciudad. Valladolid, 1999, Vol. II, p. 386.

11. Los datos referentes a los libros de actas del concejo de Valladolid proceden del trabajo de investigación en curso de D. Víctor Arenzana (Universidad de Valladolid) donde se aborda el estudio de esta fuente entre 1497 y 1520.

12. Yun Casalilla, B.: Marte contra Minerva. El precio del Imperio español, c. 1450-1600. Barcelona, 2004, pp. 51 y ss.; pp. 195 y ss.

(C) Ediciones Universidad de Salamanca / ®@ Stud. his., H. ${ }^{a}$ mod., 38, n. 1 (2016), pp. 193-222 
los dispuestos por los grandes capitales extranjeros que orientaban sus inversiones y negocios a ámbitos específicos en torno a las grandes ferias y a la Corona. Así, la figura del cambiador castellano adquirió una relevancia sin precedentes en la región, un hecho que, posiblemente, también pudo verse beneficiado por la salida del reino de los judíos, agentes financieros que hasta entonces habían ejercido como oferentes de crédito y cambiadores ${ }^{13}$.

Como dicta la lógica, los cambiadores castellanos se establecieron en los principales centros urbanos, aquellos donde el negocio alcanzaba el volumen suficiente como para ejercer su labor con seguridad y poder obtener el ansiado beneficio con sus negocios. En Burgos, por ejemplo, tenemos constancia de la presencia de cambiadores como Pedro de Mazuelo, apellido ligado a una importante familia de mercaderes ${ }^{14}$, o Bernardino de Santa María, importante financiero con una presencia más que notable durante las primeras décadas del siglo xvi; mientras que en Segovia destacan nombres como los de Fernán Pérez, Rodrigo Pérez o García de San Migue ${ }^{15}$. En estos casos, además del evidente potencial mercantil y productivo de estos centros, la instalación de algunas de las casas de la moneda más importantes de la corona favoreció la presencia numerosos cambiadores y financieros entre sus vecinos, algunos de los cuales ocuparon posiciones de relevancia en la vida política de sus respectivos concejos ${ }^{16}$.

No obstante, la actividad de los cambiadores fue especialmente intensa en dos centros que no poseían cecas pero sí disponían de un indudable atractivo para aquellos que deseaban hacer negocio con las finanzas: Medina del Campo y, sobre todo, Valladolid. El interés que mostraron los cambiadores por Medina del Campo era evidente ya que, a fines del siglo xv, sus ferias se consolidaban como las principales ferias comerciales y de pagos en la corona. En el caso de Valladolid la motivación parecía ser diferente. Su idoneidad como centro en el que establecer de forma fija una mesa de cambio respondía a varios factores: su propia dinámica comercial y ferial ${ }^{17}$, su cercanía a los otros grandes centros feriales -Medina del

13. Los cambiadores judíos Isaac Galfón (Segovia) o don Bueno (Burgos) son algunos ejemplos. Archivo General de Simancas [en adelante AGS], Registro General del Sello (en adelante RGS), leg. 1492-11, 170 (Isaac Galfón o Algfón) y leg. 1488-04, 154 (don Bueno).

14. AGS, RGS, leg. 1493-11,116

15. AGS, RGS, leg. 1498-02, 272. Al igual que ocurría en el caso de otros cambiadores castellanos, estos segovianos mantenían negocios con dos importantes agentes genoveses, Pantaleón y Martín Centurión. Los tres cambiadores citados no eran ajenos a los problemas relacionados con el impago de sus obligaciones. AGS, RGS, legs. 1498-03, 212 y 149810, 287.

16. Como ocurrió en el caso del famoso financiero Fernán Núñez Coronel quien, tras convertirse al cristianismo, fue nombrado regidor de la ciudad de Segovia. Pérez, J.: Los judíos en España. Madrid, 2005, p. 190.

17. De ello da buena cuenta la presencia de mercaderes extranjeros, como cita IgUAL Luis, D.: «Valladolid y sus circuitos económicos en relación (1475-1520)», Edad Media. Revista de Historia,

(C) Ediciones Universidad de Salamanca / ®@ Stud. his., H. ${ }^{a}$ mod., 38, n. 1 (2016), pp. 193-222 
Campo, Villalón y Medina de Rioseco- y su posición intermedia entre centros económicos de la talla de Burgos o Segovia, sin olvidar que la villa albergaba de forma estacional a la Corte y que se había convertido en sede de instituciones como la Real Chancillería. A pesar de la aparente rivalidad entre ambos centros ${ }^{18}$, la sinergia entre sus gentes y agentes era importante, pues, al igual que ocurría en el ámbito mercantil, era común encontrar en las ferias Medina del Campo a cambiadores procedentes de Valladolid (Cocón, Verdesoto, Paredes...) que, de forma estacional, también actuaban en las vecinas ferias de Medina de Rioseco y Villalón. Esta vinculación entre Valladolid y Medina del Campo a través del cambio se mantuvo durante buena parte del siglo xvi ya que, mientras Valladolid reforzaba su papel político, Medina hacía lo propio como polo financiero ${ }^{19}$.

\subsection{Los cambiadores vallisoletanos}

A fines del siglo xv e inicios del xvI, el establecimiento de cambiadores en la villa del Pisuerga fue notable y, posiblemente, superior al de otros centros mencionados. Su presencia debió crecer durante las últimas décadas del siglo xv, al menos hasta fines de los años noventa, coincidiendo con una etapa de auge dentro de la villa. Esta situación se mantuvo a pesar del empuje de Medina del Campo y de otros centros, propiciando el desarrollo de los negocios propios del cambio y giro en la villa, y de otros mejor conocidos como el préstamo, el control de la moneda o la gestión de negocios como el arrendamiento de rentas ${ }^{20}$.

Basta tomar como referencia algunos datos cuantitativos para mostrar la relevancia adquirida por los cambiadores en Valladolid. En 1497, por ejemplo, hasta 25 cambiadores llegaron a asentar sus mesas públicas a través de la pertinente obligación

15, 2014, pp. 104-108; o Villanueva Morte, C.: «La empresa familiar de los «Litta»: negocios e intereses entre Milán y España desde mediados del siglo XV», Edad Media. Revista de Historia, 10 (2009) pp. 307-341. Una presencia que se mantuvo a lo largo del siglo, como aprecia BenNASSAR, B.: «Marchands flamands et italiens a Valladolid au Xvie siècle» en Kellenbenz, H. (hrsg.): Fremde Kaufleute auf der Iberischen Halbinsel. Köllner Kolloquien, 1970, pp. 48-55.

18. Val Valdivieso, M. ${ }^{a}$ I.: «Medina del Campo en la época de los Reyes Católicos», en Lorenzo Sanz, E. (coord.): Historia de Medina del Campo y su Tierra. Valladolid, 1986, vol. I, pp. 231-314, en particular p. 274; Eadem: «Valladolid y las villas de su entorno en el tránsito de a Edad Media a la Moderna», en VV. AA.: Valladolid. Historia de una ciudad. Valladolid, 1999, Vol. I, pp. 217-242.

19. Ruiz Martín, F.: «Las ferias de Castilla», en Lorenzo Sanz, E. (coord.): Historia de Medina del Campo y su Tierra. Valladolid, 1986, vol. II, pp. 269-299.

20. Carvajal de la Vega, D. y Bonachía Hernando, J. A.: «Financieros locales en los primeros encabezamientos castellanos: Valladolid, 1496», en Borrero Fernández, M. y Peinado Santaella, R. (eds.): Agentes de los sistemas fiscales en Andalucía y los reinos hispánicos (siglos XIII-XVII). Madrid, 2015, pp. 169-192.

(C) Ediciones Universidad de Salamanca / ®@ Stud. his., H. ${ }^{a}$ mod., 38, n. 1 (2016), pp. 193-222 
por la que el titular y sus fiadores se comprometían a responder por sus deudas ante el concejo ${ }^{21}$. Este número de financieros obligados en el cambio público es elevado, sobre todo si tenemos en cuenta que en Sevilla, durante una etapa similar, se han contabilizado en torno a 13-15 cambiadores públicos sumando los «de libro» y los «de trueque» ${ }^{22}$. Resulta difícil hallar cifras similares en otros centros, más aún cuando a los cambiadores públicos podríamos sumar los nombres de otros tantos que, a pesar de estar presentes y avecindados en la villa, no asentaron en ella su mesa de cambio público. Así, no parece descabellado afirmar que el número de cambiadores asentados en Valladolid a inicios del siglo xvi debió superar con creces la treintena ${ }^{23}$. Algunos de los apellidos que copan la nómina de financieros respondían a familias especialmente conocidas en la villa, como los San Pedro, los Aranda, los Valladolid, los Monzón, los León o los Román, familias encabezadas por cambiadores que se preocuparon por mantener y transmitir su negocio y su saber a las generaciones posteriores, comportamiento que a su vez respondía a una de las características más comunes entre las nuevas elites económicas europeas ${ }^{24}$. Como estrategia orientada a conservar su posición económica, la mayor parte de estos cambiadores optó por tejer sus redes partiendo de las relaciones con sus compañeros cercanos, buscando obtener el respaldo de otros financieros en los asuntos que atañen al negocio local, sin olvidar potenciar y cuidar sus vínculos con sujetos de toda condición (espaderos, escribanos, cordoneros, armeros, mayordomos, traperos, mercaderes, etc.) cuyo apoyo también era bienvenido a la hora, por ejemplo, de obligarse por sus cambios. Esta estrategia basada en ampliar el universo de vínculos sociales y económicos resultó fundamental a la hora de reforzar su posición y de integrarse en la sociedad vallisoletana, sobre todo en casos como el de los Paredes que, a fines del siglo xv, eran unos recién llegados a la villa.

Además de cumplir con las funciones propias del cambio, el análisis de la actividad de algunos cambiadores permite observar su interés por tomar parte en la vida

21. Se obligaban los fiadores a responder hasta la cantidad de 1.000 doblas, Pino Rebolledo, F.: El primer libro de actas del ayuntamiento de Valladolid. Año 1497. Valladolid, 1990, p. 162.

22. Collantes de Terán Sánchez, A.: Sevilla en la baja Edad Media. La ciudad y sus hombres. Sevilla, 1977, pp. 376-377.

23. Sabemos que la ciudad acogió a numerosos cambiadores. Basta consultar los libros de actas de 1497, 1498 y 1499, o el alarde de Valladolid de 1503 para hacerse una idea. El número de cambiadores oscila, llegando a contabilizar 22 en el año 1500, que depositaron entre 3.000 y 500 ducados para ejercer su oficio. Bennassar, B.: Valladolid en el Siglo de Oro. Valladolid, 1989, p. 230. Por nuestra parte hemos documentado aproximadamente 30 cambiadores en 1497 según PinO Rebolledo F.: El primer libro de actas del ayuntamiento de Valladolid. Año 1497. Valladolid, 1990, p. 176. Sobre la presencia de cambiadores en Valladolid en 1503: Álvarez Bezos, S. y Carreras Zalama, A.: Valladolid en época de los Reyes Católicos según el alarde de 1503. Valladolid, 1998, pp. 182-185.

24. Las referencias a los mismos son continuas en las actas municipales hasta 1520. Vid. Nota 12. Sobre la situación europea, KAMEN, op. cit., pp. 95 y ss.

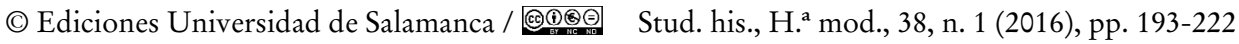


social y política de las ciudades donde se asentaron. El mundo vallisoletano nos ofrece valiosos modelos, como el de la influyente familia Verdesoto ${ }^{25}$. Esta familia, junto a otras como los López de Calatayud, supone uno de los mejores ejemplos de la rápida integración de familias dedicadas al comercio y a las finanzas en uno de los grandes regimientos de Castilla. El ascenso y la consolidación en el regimiento de varias generaciones de los Verdesoto (Alonso de Verdesoto, su hijo Rodrigo el viejo, su nieto Rodrigo de Verdesoto y su bisnieto Alonso de Verdesoto entre finales del siglo $\mathrm{xV}$ y mediados del $\mathrm{xVI}^{26}$ ) coinciden en el tiempo con las actividades financieras desarrolladas por otra rama de la familia. Los hermanos y los primos de los que ejercieron como regidores se dedicaron a reforzar su posición como cambiadores y, ocasionalmente, actuando como mercaderes o recaudadores de impuestos.

El cambiador Alonso de Verdesoto, que compartía nombre con su padre, el regidor Alonso de Verdesoto ${ }^{27}$, era a su vez hermano del también regidor Rodrigo de Verdesoto. Alonso desarrolló su actividad entre Valladolid y Medina del Campo, centro donde era asiduo a inicios de la década de 1490, seguramente aprovechando los buenos negocios que hacía en el lugar de procedencia de su madre, Isabel Sánchez ${ }^{28}$. En Valladolid, además de actuar como cambiador, Alonso mantuvo una estrecha relación con el gobierno urbano, recibiendo y entregando libranzas del concejo, recaudando sisas en la puerta del $\mathrm{Campo}^{29} \mathrm{o}$ actuando como contraste en $1504^{30}$. El cambiador procuró guiar los pasos de sus hijos desde temprano. En 1489, mientras Alonso de Verdesoto se encontraba preso por razones hoy desconocidas, sus hijos, García de Verdesoto y Gonzalo de Verdesoto -que por aquel entonces debía tener 19 años ${ }^{31}$-, intentaron asentar su negocio en Medina del Campo, encontrando la oposición de poderosos agentes como el florentino

25. Martín Romera, M. ${ }^{a}$ Á.: Las redes sociales de la oligarquía de la villa de Valladolid (1450-1520). Tesis doctoral, Universidad Complutense de Madrid, 2012, pp. 234 y ss.

26. Rodrigo de Verdesoto el viejo es sustituido en 1518 por su hijo, Rodrigo de Verdesoto, a quien sucedió como regidor su hijo, Alonso de Verdesoto. Idem, p. 243.

27. Sección Nobleza del Archivo Histórico Nacional, Toreno, c. 2, D. 41, f. 6r-v, registro 61. Su madre era Isabel Sánchez.

28. Martín Romera, M. á.: Las redes sociales de la oligarquía de la villa de Valladolid (1450-1520). Tesis doctoral, Universidad Complutense de Madrid, 2012, p. 240.

29. En la probanza de la hidalguía de Juan Fernández de Paredes, Gonzalo de Verdesoto cita a su padre como encargado de la recaudación de una sisa en la puerta del Campo que consistía en el pago de un real por cada carreta que entraba o salía de la villa. Archivo de la Real Chancillería de Valladolid [en adelante ARChV], Registro de Ejecutorias, c. 660, 7.

30. Archivo Municipal de Valladolid [en adelante AMV], Libros de actas, 2, fol. 71 r-v $(1502 / 12 / 14)$.

31. En la probanza de la hidalguía de Juan Fernández de Paredes, realizada en torno a 1541, Gonzalo de Verdesoto aparece como testigo y declara tener 71 años, por lo que debió nacer en 1470. ARChV, Registro de Ejecutorias, c. 660, 7.

(C) Ediciones Universidad de Salamanca / ®@ Stud. his., H. ${ }^{a}$ mod., 38, n. 1 (2016), pp. 193-222 
DAVID CARVAJAL DE LA VEGA

CAMBIADORES Y ELITES URBANAS: EL AUGE DE ANTONIO DE PAREDES

Y SU FAMILIA EN VALLADOLID A INICIOS DEL SIGLO XVI

Francisco del $\mathrm{Nero}^{32}$. La pugna por la presencia en los boyantes centros financieros comenzaba a ser notable. Con ello, los hermanos Verdesoto daban los primeros pasos de lo que fue una intensa vida financiera centrada, al igual que su padre, en Medina del Campo, Valladolid ${ }^{33} \mathrm{y}$, en menor medida, en otros centros feriales como Medina de Rioseco ${ }^{34}$. A fines del siglo xv e inicios del xvi, el éxito empresarial de los Verdesoto se hizo patente en los negocios que mantuvieron con importantes agentes como el cambiador Ochoa de Salinas con quien, además de compartir una compañía $a^{35}$, mantenían constantes relaciones en el entorno de la corte, donde Gonzalo de Verdesoto también figuraba como cambiador ${ }^{36}$. El universo de relaciones sociales impulsado por esta familia era un ejemplo a seguir por sus más allegados.

A pesar de su aparente éxito, la suerte no fue del todo propicia con la familia de cambiadores. Además de los pleitos surgidos tras la muerte de García de Verdesoto, que fueron atendidos por su padre ${ }^{37}$, hay que sumar los problemas por los que atravesó Gonzalo de Verdesoto. Este debió enfrentarse a acusaciones de fraude y a procesos por deudas derivadas, entre otras causas, de las fianzas que otorgó a los miembros de otra importante familia de cambiadores vallisoletanos: los Arand ${ }^{38}$. No conocemos muchos más datos relevantes de la rama de los financieros Verdesoto, lo que pone de manifiesto la fragilidad de los financieros ante un entorno económico en proceso de consolidación. Por el contrario, aquellos que accedieron al regimiento lograron perpetuar el nombre de una familia cuyo

32. AGS, RGS, leg. 1490-09, 171. El florentino pretendía cobrarles en exceso por el derecho de poner su mesa de cambio.

33. Martín Romera, M. ${ }^{a}$ A.: Las redes sociales de la oligarquía de la villa de Valladolid (1450-1520). Tesis doctoral, Universidad Complutense de Madrid, 2012, pp. 246-248.

34. AGS, RGS, 150405, 279 (1504-05-21), García de Verdesoto desarrolló parte de su negocio en las ferias de Medina de Rioseco, registrando en sus libros las actividades de importantes agentes italianos como los Centurión.

35. Carvajal de la Vega, D.: Crédito privado y deuda en Castilla (1480-1521). Tesis doctoral, Universidad de Valladolid, 2013, pp. 618-621.

36. AGS, RGS, leg. 1505-08, 347. Las referencias a los Verdesoto son continuas en REPRESA, A.: Libro mayor del «banquero de corte» Ochoa de Salinas (1498-1500). Bilbao, 1980, fols. 22v-23r o 30v-30r, entre otras anotaciones.

37. Martín Romera, M. ${ }^{a}$ Á.: Las redes sociales de la oligarquía de la villa de Valladolid (1450-1520). Tesis doctoral, Universidad Complutense de Madrid, 2012, p. 247.

38. Sobre los problemas de Gonzalo de Verdesoto relacionados con sus deudas impagadas, sus negocios y fianzas con el cambiador Jerónimo de Aranda, véanse AGS, RGS, legs. 1504-11, 298; 150411, 93; 1505-10, 295; 1506-10, 413; 1507-09, 23; 1507-10, 344; incluso se emitió orden de prendimiento contra él: AGS, RGS, leg. 1507-08, 205. Los negocios y relaciones con los Aranda eran anteriores, en particular con Antón García de Aranda: Álvarez Bezos, S. y Carreras Zalama, A.: Valladolid en época de los Reyes Católicos según el alarde de 1503. Valladolid, 1998, p. 184.

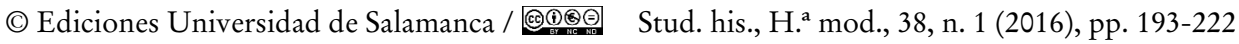


ascenso en el seno de la oligarquía vallisoletana recuerda mucho al de otros grupos familiares que, en épocas muy cercanas, aprovecharon sus relaciones y negocios en torno al cambio para alcanzar fines análogos.

Las aspiraciones de estas nuevas familias chocaron en no pocas ocasiones con la oposición de la oligarquía local dominante, tradicionalmente vinculada a los linajes Tobar y Reoyo ${ }^{39}$, y con la competencia de otros hombres de negocio deseosos de obtener reconocimiento en la villa. Quizá por ello, aquellos que buscaban el ascenso eran cuidadosos a la hora de establecer sus relaciones económicas y sociales, buscando ganarse la confianza de sus iguales, entablando alianzas matrimoniales o intentando cultivar su buena fama y combatir las injurias y el descrédito incentivado por sus enemigos. Estas estrategias fueron especialmente necesarias y útiles en el caso de los cambiadores, acusados con frecuencia de usureros por su labor como prestamistas. Un buen ejemplo de todo lo citado anteriormente lo encontramos en la figura del cambiador vallisoletano Antonio de Paredes, cuyo origen, trayectoria vital y sucesión ponen de manifiesto la capacidad de un cambiador para ascender entre sus vecinos valiéndose de los beneficios que le reportaron las finanzas y su capacidad de relación.

\section{Antonio de Paredes y su familia}

Uno de los problemas más importantes y complejos con los que tuvo que lidiar el ya citado cambiador Gonzalo de Verdesoto fue el pleito que mantuvo con Ochoa de Salinas a causa de unas deudas impagadas tras la disolución de su compañía ${ }^{40}$. A raíz de este proceso, juzgado ante el Consejo de Castilla, surgieron otros litigios paralelos en los que Gonzalo de Verdesoto se vio obligado a pleitear con el representante de Ochoa de Salinas, el cambiador Antonio de Paredes. A pesar de ser menos conocido que los Verdesoto y de mantener vínculos más débiles con el regimiento de Valladolid, Antonio de Paredes fue un personaje relevante en su tiempo, logrando cierta influencia en la villa durante la última década del siglo xv y los primeros años del xvi como así lo demuestran su historia y su memoria.

39. Sobre la importancia de los linajes en Valladolid véase RucQuoi. A., op. cit., y GuTiérRez Alonso, A.: «Sociedad y poder. La oligarquía vallisoletana y sus relaciones con otras instancias de poder», VV. AA.: Valladolid. Historia de una ciudad. Valladolid, 1999, vol. II, pp. 383 y ss.

40. ARChV, Pleitos Civiles, Masas (F), c. 3174-3.

(C) Ediciones Universidad de Salamanca / ®@ Stud. his., H. ${ }^{a}$ mod., 38, n. 1 (2016), pp. 193-222 
DAVID CARVAJAL DE LA VEGA

CAMBIADORES Y ELITES URBANAS: EL AUGE DE ANTONIO DE PAREDES

Y SU FAMILIA EN VALLADOLID A INICIOS DEL SIGLO XVI

\subsection{El cambiador Antonio de Paredes}

A mediados del siglo xvi eran muchos los vallisoletanos que aún recordaban los primeros años de la familia Paredes en Valladolid. A tenor de ciertas informaciones proporcionadas por varios vecinos (como el ya conocido Gonzalo de Verdesoto), la familia Paredes se asentó en la villa del Esgueva en torno a la década de 1470, en concreto cuando Juan de Paredes, padre de Antonio, apareció en la villa y contrajo matrimonio con Beatriz de la Peña ${ }^{41}$. Juan era hijo de Juan Sanz de Paredes y de María Hernández Angulo ${ }^{42}$ y procedía de San Llorente, localidad situada en la merindad de Losa, al norte de Burgos, lindando con el territorio de Vizcaya ${ }^{43}$. Al parecer, el padre del cambiador se dedicaba al comercio del hierro, actividad relacionada con su lugar de procedencia y que posiblemente le llevó a asentarse en el entorno vallisoletano en busca de las oportunidades que le ofrecía el desarrollo comercial del interior peninsular, y de la villa del Esgueva en particular. Juan de Paredes mantuvo su negocio en una de los puntos neurálgicos de la geografía urbana, en calle de Santiago, cerca de la puerta del Campo por la que varias personas recordaban haberle visto cruzar con su carreta -sin pagar impuesto alguno, pues era hidalgo ${ }^{44}$ - destino a una u otra feria, según correspondiese. El negocio debió prosperar, síntoma de que las oportunidades económicas eran reales, y con el tiempo incorporó a la actividad a su hijo, a quien también recordaban a bordo de una carreta.

41. ARChV, Registro de Ejecutorias, c. 660, 7.

42. Según la información contenida en DÁvila, V: Próceres Merideños. Caracas, 1918, p. 103, Juan Sanz de Paredes era señor de la casa solariega de Torre de Paredes; su hijo primogénito fue Lope Sanz de Paredes, señor de la casa solariega citada. También aparece como hijo Juan de Paredes y, posiblemente, Pedro Alfonso de Paredes, escribano de cámara del rey en 1444, avecindado en Paredes de Nava (CAÑas Gálvez, F. de P.: Burocracia y cancillería en la corte de Juan II de Castilla (1406-1454). Estudio institucional y prosopográfico. Salamanca, 2013, p. 420). La presencia de personajes con este apellido es frecuente en esta localidad durante el período estudiado, a lo que se suma lo común de un apellido derivado del topónimo. También es frecuente encontrar a varios Paredes al servicio de las instituciones castellanas, como ocurrirá con el receptor de penas de la Real Chancillería de Valladolid, Francisco de Paredes, con las primeras referencias en torno a 1497-1498 (AGS, RGS, leg. 1497-08, 198 y ARChV, Registro de Ejecutorias, c. 126, 20) de quien no conocemos hasta ahora vínculos familiares con la rama analizada en este trabajo.

43. Dávila, V.: Próceres Merideños. Caracas, 1918, p. 256 y Picón-Parra, R.: Fundadores, primeros moradores y familias coloniales de Mérida (1558-1810). Caracas, 1988, p. 396. Según la información ofrecida por Dávila, San Llorente 30 vecinos, todos hidalgos. También en VV. AA., Fundadores, primeros moradores y familias coloniales de Mérida (1558-1810). Caracas, 1988, p. 396.

44. ARChV, Registro de Ejecutorias, c. 660, 7.

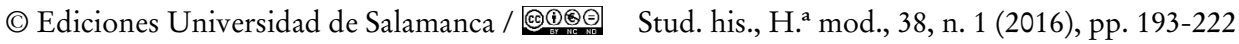


DAVID CARVAJAL DE LA VEGA

CAMBIADORES Y ELITES URBANAS: EL AUGE DE ANTONIO DE PAREDES

Y SU FAMILIA EN VALLADOLID A INICIOS DEL SIGLO XVI

Antonio de Paredes nació en torno a $1463^{45}$. Tras dedicarse al comercio del hierro con su padre, las primeras noticias que poseemos de su actividad ya como cambiador se remontan a la década de 1490, una etapa en la que mostró un gran interés por hacer negocio allí donde creía tener una oportunidad para ello. Al igual que su padre, estableció su vida y sus negocios en Valladolid, manteniendo su hogar en el barrio de la Costanilla ${ }^{46}$, donde también poseían sus casas otros financieros como el ya citado García de Verdesoto, lo que le permitió compartir espacios con muchos de los cambiadores que acabarían por ser sus socios, compañeros, familiares, amigos o enemigos. Muestra de su interés por reforzar su posición en la villa y por tejer lazos con otros financieros, Antonio de Paredes contrajo matrimonio con Mayor López de Villalón, hija del cambiador Alvar González de Villalón y de Isabel Gutiérrez, y hermana del también cambiador Juan de Villalón ${ }^{47}$.

En el ámbito estrictamente profesional, el cambiador asentó su mesa en Valladolid tras obligarse ante el concejo, al menos en el año $1498^{48}$. Al parecer, Antonio gestionaba y controlaba sus negocios desde la villa, donde conservaba buena parte de sus libros y escrituras ${ }^{49}$, limitando sus movimientos fuera de Valladolid, donde era común encontrarlo reclamando deudas o entregando a sus acreedores poderes para que cobrasen derechos pendientes ${ }^{50}$. Su presencia en la villa, como la de tantos otros cambiadores y mercaderes -Cocón, Portillo, etc.- dependía de la celebración de las ferias circundantes a las que acudía con asiduidad.

45. Según el propio Antonio de Paredes en torno a 1507-1509 tenía 45 años: $I I^{\circ}$ Testigo. Antonio de Paredes, canbiador, veçino de Valladolid, de hedad de XLV annos. Dixo, siendole mostrada la dicha hoja en la partida contenido, que conoçia e conoçe la letra que esta escrita en la margen de la dicha hoja ser letra del dicho Alonso de Verdesoto, e que tal le pareçe realmente aunque este testigo no gelo vio escrivir. ARChV, Pleitos Civiles, Pérez Alonso (F), c. 925-2.

46. AHPV, Protocolos, c. 14065/10, fols. 729v-732r.

47. AHN, Clero Regular Secular, leg. 7859. Se conservan documentos fechados en 1511 del pleito que mantuvieron los hijos de Alvar González de Villalón con el Monasterio de San Pablo por la posesión de la mitad de diez pares de casas que tenía el difunto cambiador en el «barrionuevo» de Valladolid.

48. Asiento por el que se obliga ante el concejo como cambiador. Presenta como fiadores a Juan Catalán y Pedro de Cuéllar. 1498, enero, 23. (AMV, Libros de Actas, 1, fol. 40v-41r).

49. El cambiador afirmaba como testigo de un pleito que parte de sus papeles y contratos, los guardaba en Valladolid, lo que le impedía presentar ante los alcaldes de Medina del Campo una cédula en la que aparecían litigantes. ARChV, Pleitos Civiles, Pérez Alonso (F), c. 192, 2.

50. Como muestra el poder entregado a Álvaro de Benavente y a Alonso de Espinosa, tesoreros de la Santa Cruzada, para que cobrasen de Francisco de la Parra, vecino de Arévalo, mercader y prestatario de Antonio de Paredes, la cantidad de 138.800 mrs. AHPV, Protocolos, c. 32, fols. 257-258, 1519.

(C) Ediciones Universidad de Salamanca / ®@ Stud. his., H. ${ }^{a}$ mod., 38, n. 1 (2016), pp. 193-222 
La más que demostrada capacidad financiera de Antonio de Paredes supuso un buen reclamo para que numerosos agentes financieros acudiesen al cambiador en busca de liquidez o, simplemente, de apoyo financiero, actuando como fiador en diversos negocios. Por ejemplo, el cambiador aparece involucrado, junto a otros cambiadores, en el mundo de la fiscalidad a partir del desarrollo del primer encabezamiento de alcabalas de Valladolid a fines del año 1495. En esta ocasión, Antonio actuó como fiador de Álvaro de Ocaña, un financiero dedicado al negocio de las rentas que pugnaba por hacerse con la codiciada alcabala de la paja, leña, fruta y madera ${ }^{51}$. Poco después, en 1499, el financiero no dudó en prestar su apoyo financiero a otro agente, Antón de Burgos, receptor de las alcabalas y privilegios por parte del concejo, ya que este se había obligado por la nada desdeñable cantidad de un millón de maravedís ${ }^{52}$. Otros ejemplos similares confirman la actividad como avalista de Antonio de Paredes, pues sabemos que continuó otorgando su apoyo a diferentes agentes, arrendatarios de rentas u obligados como Francisco Gómez, quien se había obligado por el servicio de la pescadería de Valladolid y había presentado ante el concejo una cédula de Antonio de Paredes donde constaba una fianza por $365.000 \mathrm{mrs}^{53}$. Esta actividad, lejos de ser un simple negocio, permite visualizar hasta qué punto el cambiador expandía un tipo de relación que, más allá de lo estrictamente económico, requería de conocimiento mutuo y de confianza entre las partes.

Además de su participación como fiador, Antonio de Paredes se implicó de forma directa en otras empresas vinculadas a la economía de la villa como ocurrió en torno a los años 1498 y 1499, cuando ejerció como receptor de las alcabalas ${ }^{54}$. El interés por el negocio fiscal debió ser grande y pareció intensificarse durante estos años, puesto que también figuraba, junto a Pedro de Montesor, como tesorero del encabezamiento de Valladolid, Infantazgo, Merindad de Cerrato y otros partidos, exigiendo al concejo de la villa el pago de parte del encabezamiento de $1499^{55}$. Sus relaciones con el concejo comenzaban a ser constantes, ya fuese a través del

51. Carvajal de la Vega, D. y Bonachía Hernando, J. A.: «Financieros locales en los primeros encabezamientos castellanos: Valladolid, 1496», en Borrero Fernández, M. y Peinado Santaella, R. (eds.): Agentes de los sistemas fiscales en Andalucía y los reinos hispánicos (siglos XIII-XVII). Madrid, 2015, pp. 169-192.

52. AMV, Libros de Actas, 1, fol. 231 (1499/05/26-29).

53. AMV, Libros de Actas, 2, fol. 234r-v (1506/05/06).

54. AMV, Libros de Actas, fol. 193v (1498) y Libros de Actas, 1, fol. 230v-231r (1499/05/17). Bonachía Hernando, J. A.: «El encabezamiento de alcabalas de Valladolid (1496-1501). Los sistemas de recaudación», en Bonachía Hernando, J. A. y Carvajal de la Vega, D. (eds.): Los negocios del hombre. Comercio y rentas en Castilla. Siglos XV y XVI. Valladolid, 2012, pp. 107-146, en especial, pp. 317-319.

55. AMV, Libros de Actas, 1, fol. 303r (1500/09/14).

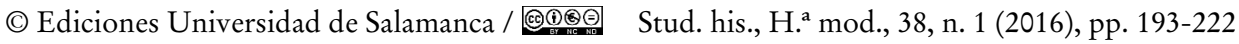


DAVID CARVAJAL DE LA VEGA

CAMBIADORES Y ELITES URBANAS: EL AUGE DE ANTONIO DE PAREDES

Y SU FAMILIA EN VALLADOLID A INICIOS DEL SIGLO XVI

negocio fiscal o desde otros ámbitos. Más allá de estas tensiones puntuales con la institución, debió existir una relación de cercanía, colaboración y confianza entre el financiero y el gobierno urbano. Como muestra de ello, y además de ejercer como cambiador público, sabemos que Antonio de Paredes ejerció como prestamista del concejo ${ }^{56}$, como receptor y pagador de ciertas rentas, y también fue nombrado veedor -junto al cambiador Alonso Román-, recibiendo el encargo de examinar las pesas y el marco que debía fabricar el platero Francisco de Andino para el concejo ${ }^{57}$.

Fuera del ámbito vallisoletano, Antonio de Paredes mantuvo fuertes vínculos con importantes financieros castellanos como el ya citado Ochoa de Salinas ${ }^{58}$, a quien representó en sus pleitos en Valladolid, de donde este último había huido por temor a los Verdesoto. El papel desempeñado por Antonio de Paredes en este asunto fue esencial, ya que se presentó como parte ante los jueces de la Cofradía de la Misericordia de Valladolid -de la que participaban mercaderes y cambiadores- para solicitar el pago de 15.088 mrs. que debía Alonso de Verdesoto a la compañía que Ochoa mantuvo con Gonzalo de Verdesoto, hijo del deudor. Dado el carácter extraordinario del caso, derivado de la consideración de Ochoa de Salinas como cambiador de corte, en noviembre de 1503, según una cédula firmada por la propia reina, se ordenó que el pleito pasase al Consejo Real, instancia donde se trataba otro proceso por la liquidación de la compañía entre ambos cambiadores. Desde ese momento, Antonio de Paredes quedó al margen del pleito, aunque ya hubiese mostrado su intención de ejercer como firme defensor de su compañero ${ }^{59}$. Más allá de este proceso, tan revelador de las relaciones y tensiones entre financieros, no deja de ser sintomático que Antonio de Paredes aparezca como cambiador en la corte -al igual que los Verdesoto-, lo que nos advierte sobre el nivel de vinculación con la administración-recordemos que también era receptor de las alcabalas-. Su cambio en la corte era la plataforma idónea para acrecentar

56. AMV, Libros de Actas, 1, fol. 143r. Antonio de Paredes y Alonso de Verdesoto prestaron $45.200 \mathrm{mrs}$. al concejo vallisoletano para que este realizase una importante compra de telas con motivo del recibimiento de la princesa Isabel en 1947.

57. AMV, Libros de Actas, 1, fol. 309r.-310v (1500/10/12). El mismo día los cambiadores declararon que lo realizado por Francisco Andino valía 14 ducados: el peso de oro, 1 ducado; el peso de plata un poco mayor, 2 ducados; el peso de plata un poco mayor, 3 ducados; el peso de plata un poco mayor, 8 ducados y el marco de 16 marcos, vale 1.000 mrs.

58. García Fernández, E.: «Hombres y mujeres de negocios del País Vasco en la Baja Edad Media», en Bonachía Hernando, J. A. y Carvajal de la Vega, D. (eds.): Los negocios del hombre. Comercio y rentas en Castilla. Siglos XV y XVI. Valladolid, 2012, pp. 107-146, en especial pp. 134-135.

59. ARChV, Pleitos Civiles, Masas (F), c. 3174, 3. ARChV, Registro de Ejecutorias, c. 187, 11 (1504).

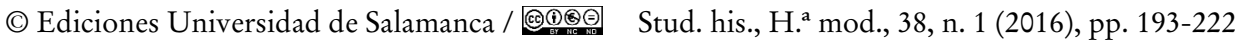


su capital social y mantener relaciones con relevantes personajes como fueron, entre otros, el tesorero Gonzalo de Baeza, el secretario Francisco de Madrid, mercaderes del entorno burgalés como Diego de Castro, estante en Londres, miembros de la familia Maluenda y, también, con sus vecinos vallisoletanos (de nuevo los Verdesoto, los Cocón, los León, los Daza...) e instituciones religiosas de la villa, ya fuera a través del Padre Vicario de San Benito de Valladolid, o de forma directa, como ocurrió con el monasterio de San Francisco, lugar que tuvo un especial significado en la vida del cambiador ${ }^{60}$.

Aparte del cambio en la corte, sus negocios más importantes fuera de Valladolid se desarrollaron en las localidades que albergaron las principales ferias castellanas. Además de la experiencia mercantil que compartió con su padre, Antonio de Paredes era asiduo de las ferias de Medina del Campo desde inicios de la década de 1490 donde, aprovechando el auge ferial, establecía su cambio y concertaba algunos de sus tratos más importantes ${ }^{61}$. El cambiador era un fiel reflejo de financiero integrado en el conocido «ciclo ferial» castellano durante sus primeros años de consolidación ${ }^{62}$. Entre los negocios más destacados estaban el préstamo y el cobro de derechos, el giro de letras y otras operaciones financieras con agentes castellanos y extranjeros, sin olvidar la actividad cambiaria. Muestra de su notoria capacidad, sabemos de su implicación en el desarrollo de las ferias de Medina del Campo, en las que llegó a ejercer, junto a otros cambiadores vallisoletanos como García de Verdesoto, Pedro de Portillo o García de Cocón, como depositario de las fianzas y las penas recibidas por las autoridades de la villa ${ }^{63}$, puesto para el que sin duda era necesario poseer cierta capacidad económica.

Aprovechando los flujos generados por el ciclo ferial, el cambiador orientó parte de su actividad como prestamista hacia la financiación de hombres de negocio procedentes de su entorno geográfico más cercano (Medina del Campo y Valladolid), con quienes era sencillo acordar el pago de la deuda en centros como Medina de Rioseco o Villalón. Entre los prestatarios encontramos a cambiadores, mercaderes, sastres y otros sujetos que figuran en los contratos como meros vecinos, lo que nos muestra que el cambiador, en principio, no

60. Datos obtenidos de las cuentas pertenecientes al cambio de Paredes entre los años 14981499 insertas en el Libro mayor del «banquero de corte» Ochoa de Salinas (1498-1500). Bilbao, 1980: para 1498 , fols. $14 \mathrm{v}-15 \mathrm{r}$; y para 1499 , fols. $51 \mathrm{v}-52 \mathrm{r}$ y $118 \mathrm{v}-119 \mathrm{r}$.

61. En torno a 1497 Antonio de Paredes reconocía tener cambio en Medina del Campo, ARChV, Pleitos Civiles, Pérez Alonso (F), c. 192, 2.

62. Carande, R.: Carlos V y sus banqueros. Barcelona, 1987, vol. 1., La vida económica en Castilla, capítulo XI: Bancos y ferias.

63. ARChV, Registro de Ejecutorias, c. 176, 8; 1503, enero, 3.

(C) Ediciones Universidad de Salamanca / ®@ Stud. his., H. ${ }^{a}$ mod., 38, n. 1 (2016), pp. 193-222 
tenía problema en ofrecer su dinero a personas con quienes, probablemente, mantenía relación ${ }^{64}$. Eso no significa que no cuidase de sus intereses ni actuase en defensa de los mismos con toda la fuerza que la ley le otorgaba, como se aprecia en el pleito entablado con García de Ledesma y Fernando de Ledesma, regidores zamoranos a quienes reclamó el pago de un préstamo de $19.000 \mathrm{mrs}$. que les concedió en Medina del Campo en $1495^{65}$. Su sobrada capacidad como agente financiero y la confianza que transmitía a muchos de sus compañeros fueron razones suficientes para recibir varios poderes de mercaderes foráneos capacitándole para cobrar deudas pendientes. De este modo, Antonio de Paredes se hizo cargo del cobro de $73.525 \mathrm{mrs}$. de diversos deudores en nombre del mercader Juan Pérez de Mieros (Calatayud) y de 406.074 mrs. en representación del también mercader Pedro Villar (Barcelona), esta vez junto a su hijo Francisco. Más allá del mero traspaso de derechos, este tipo de operaciones siguen dibujando el perfil de un financiero consolidado y bien considerado, pilares esenciales para progresar en la sociedad castellana y vallisoletana a inicios del xvi.

Tabla 1. Derechos recibidos por Antonio de Paredes en Medina del Campo (16 y 17 de julio de 1515$)^{66}$

\begin{tabular}{|c|c|c|c|c|}
\hline & NOMBRE & OCUPACIÓN & VECINDAD & CANTIDAD \\
\hline \multirow{8}{*}{ 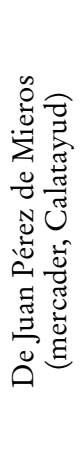 } & Bartolomé del Pilar & Vecino & Alburquerque & 20000 \\
\hline & Juan Vázquez & Vecino & Toledo & 16000 \\
\hline & Pedro Álvarez de Toledo & Mercader & Toledo & 10500 \\
\hline & Pedro y Gonzalo Sánchez de San Pedro & Mercader & Toledo & 8100 \\
\hline & Alonso Pérez de Jarada & Mercader & Toledo & 7800 \\
\hline & Antonio de Ríos & Mercader & Murcia & 5980 \\
\hline & Juan del Rincón & Mercader & Ocaña & 5145 \\
\hline & \multicolumn{3}{|l|}{ Total } & 73525 \\
\hline
\end{tabular}

64. En particular, a través de obligaciones con agentes como el mercader medinense Diego Alonso, que le debía 62.600 mrs. (AHPV, Protocolos, c. 7330, fol. 350r.), o de préstamos como el otorgado a Francisco de Mercado, vecino de Madrigal, por 8.190 mrs. (AHPV, Protocolos, c. 7330 , fol. 407v) o el concedido a Pedro de Valladolid, sastre, vecino de Valladolid, por 6.000 mrs. (AHPV, Protocolos, c. 7330, fol. 416v).

65. ARChV, Pleitos Civiles, Pérez Alonso (F), c. 192, 1.

66. AHPV, Protocolos, c. 7330, fol. 538 (1515, julio, 16) y fols. 568r-569v (1515, julio, 17).

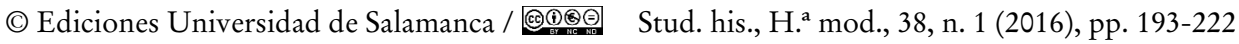


DAVID CARVAJAL DE LA VEGA

CAMBIADORES Y ELITES URBANAS: EL AUGE DE ANTONIO DE PAREDES

Y SU FAMILIA EN VALLADOLID A INICIOS DEL SIGLO XVI

\begin{tabular}{|c|c|c|c|c|}
\hline & NOMBRE & OCUPACIÓN & VECINDAD & CANTIDAD \\
\hline \multirow{25}{*}{ 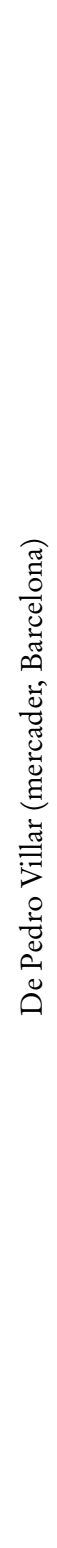 } & Martín Alonso de Santa María & Mercader & Toledo & 67832 \\
\hline & Pedro de Villacís & Vecino & Medina de Rioseco & 54117 \\
\hline & Juan de Valladolid & Mercader & Sevilla & 44605 \\
\hline & Hernando de Jerez & Mercader & Sevilla & 32794 \\
\hline & Jorge González & Vecino & Zafra & 25215 \\
\hline & Bernardino Álvarez & Vecino & Medina de Rioseco & 18150 \\
\hline & Francisco & Platero & Medina de Rioseco & 16304 \\
\hline & Cristóbal de Aller & Platero & Valladolid & 16184 \\
\hline & Pedro de Bretaña & Mercero & Medina del Campo & 15350 \\
\hline & Gil de Villanueva & Mercader & Úbeda & 15080 \\
\hline & Gonzalo de Saldaña & Mercader & Saldaña & 12744 \\
\hline & Pedro de Valladolid & Platero & Medina de Rioseco & 12347 \\
\hline & Pedro de Gaybor & Mercader & Santiago & 11769 \\
\hline & Juan de Dios & Vecino & Santiago & 11675 \\
\hline & Martín de Haro & Mercader & Córdoba & 9665 \\
\hline & Bartolomé Díez & Especiero & Medina del Campo & 7750 \\
\hline & Gonzalo de Segura & Mercader & Toledo & 7500 \\
\hline & Lope Martínez & Mercader & Córdoba & 6200 \\
\hline & Alonso de Valladolid & Mercader & Valladolid & 5268 \\
\hline & Alonso de Baeza & Mercader & Baeza & 5225 \\
\hline & Diego Gómez & Mercader & Córdoba & 4500 \\
\hline & Francisco de Villalón & Vecino & Ponferrada & 3600 \\
\hline & Tristán de Tovar & Vecino & Medina del Campo & 1600 \\
\hline & Juan Llorente & Vecino & Cuenca & 600 \\
\hline & Total & & & 406074 \\
\hline
\end{tabular}

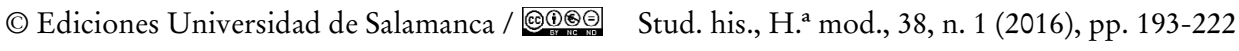


El otro ámbito de negocio en el que destacó la actividad de Antonio de Paredes fue el que se refiere propiamente al cambio y al giro. Aprovechando los períodos de feria en Medina del Campo, Antonio de Paredes llevó a cabo operaciones de cambio de moneda por importes elevados, como lo demuestran los $100.000 \mathrm{mrs}$. que había entregado en ducados, castellanos y doblas de oro a Antonio de Portillo, mercero de Medina del $\mathrm{Campo}^{67}$, mostrando una disponibilidad y una capacidad manifiesta para llevar a cabo este tipo de transacciones. En cuanto al giro, los documentos conservados ponen de relieve, una vez más, hasta dónde se extendían los negocios del cambiador. En este sentido destacaron las suscripciones que Antonio de Paredes hizo de sendas letras de cambio junto a Francisco de Valladolid, mercader vecino del citado lugar, Juan Pérez de Nueros, mercader de Calatayud, y Pedro de Portillo, mercero de Medina del Campo, para pagar en Valencia a Césare Barze los 100 y 200 castellanos de oro de las dos primeras letras y 150 castellanos, por la tercera, a los genoveses Andrea Gentil y a Tomás y Nicolao Spinola ${ }^{68}$. Muchos de los italianos presentes en el norte peninsular mantenían estrechas relaciones con los banqueros castellanos, como de hecho ocurrió con Antonio de Paredes que, además, mantuvo relaciones con los Carducho o con los representantes de la familia genovesa Negro. Tamaño número de operaciones también le causó problemas, como se aprecia en el pleito que entabló con el milanés Leonardo Rétulo, a quien había librado 200 ducados en el cambio de Verdesoto para hacer frente al pago de una cédula -al parecer falsa- que supuestamente había girado en Bernabé Negro en Toledo ${ }^{69}$.

Además de sus intereses en Medina del Campo, Antonio de Paredes también instaló en tiempos de feria su cambio en los otros dos grandes núcleos feriales del norte: Villalón y Medina de Rioseco. En ambos centros seguía desarrollando los mismos negocios, prestando o, por ejemplo, recibiendo los derechos de varios mercaderes que habían confiado en su persona para tal labor. Antón López de Calatayud, mercader de Zaragoza ${ }^{70}$, o el medinense Lope de Medina ${ }^{71}$, con quien debió mantener una larga relación, figuran como algunos de sus contactos más destacados durante las dos primeras décadas del siglo XVI.

67. AHPV, Protocolos, c. 7330 , fol. 321v.

68. AHPV, Protocolos, c. 7330 , fols. $294 \mathrm{r}-\mathrm{v}$ y fol. $326 \mathrm{r}$.

69. ARChV, Pleitos Civiles, Pérez Alonso (F), c. 192, 2.

70. En 1513, durante la feria de Cuaresma, recibió $1.032 \mathrm{mrs}$. AMV, Fondo Hospital de Esgueva, caja 404-62 y en la feria de Cuaresma de 1515 recibió 1.571 mrs. AMV, Fondo Hospital de Esgueva, caja 404-69. Herrero Jiménez, M. y Díaz Blanco, M. E.: El archivo del mercader Hernando Daza Medina ([1505]-1566). Valladolid, 2009.

71. Ibidem. En la feria de Villalón de 1517 recibió 8.000 mrs. para Lope de Medina, AMV, Fondo Hospital de Esgueva, caja 404-92, mercader que al menos desde 1506 había confiado este tipo de operaciones al cambiador, AMV, Fondo Hospital de Esgueva, caja 404-66.

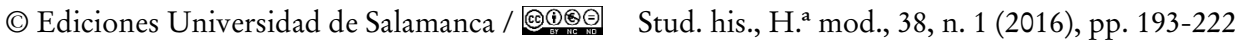


La actividad de los cambiadores, a pesar de ser tan necesaria, no siempre gozó del prestigio que intentaron cultivar. Como en otros tantos lugares, la práctica de un profesional de las finanzas se vio envuelta en constantes quejas, reclamaciones y denuncias por la comisión de usuras, abusos y otros delitos. Por ejemplo, la condición de Antonio de Paredes como depositario de las penas en Medina del Campo le llevó a enfrentarse a oficiales como Rodrigo de Ribadeneira, alguacil en la villa, que reclamaba al cambiador el pago de $1.600 \mathrm{mrs}$. por los derechos que le correspondían como oficial en un proceso judicial desarrollado en Medina del Campo ${ }^{72}$. Además de otros problemas como el expuesto, una de las acusaciones más graves a las que se enfrentó el financiero vallisoletano ante la justicia se refería al ataque contra su honradez en el ejercicio de su actividad. Haciendo uso de uno de los argumentos más recurrentes, el fiscal de la Real Chancillería de Valladolid y los deudores de Antonio de Paredes decidieron cuestionar su honor como cambiador, acusándole de haber cometido usuras ${ }^{73}$. Aunque el pleito en cuestión vino motivado por una denuncia del fiscal, es posible que el proceso estuviese movido por el interés de otros cambiadores -como Álvaro de Cuéllar-y mercaderes que trataban de denostar al cambiador. La denuncia presentada ante la Real Chancillería argumentaba que Antonio de Paredes había cometido alogro en sus operaciones de crédito:

e por los prestar llevando muchas contias de las que prestaba e avia fecho contrabtos en fraude de usuras, espeçialmente dixo que presto a Rodrigo Perez e Alonso Perez, de Medina de Rioseco, treynta e dos mill mrs. a pagar a çierto tiempo; e porque no los podieron pagar al dicho termino, el dicho Paredes les avia fecho obligaçion por treynta e çinco mill mrs. a Albaro de Cuellar cambiador, a pagar a çierto termino; e porque no los podieron pagar al dicho termino, el dicho Paredes les avya obligado por quarenta e syete mill mrs. a Pedro de Palaçios; e porque non los podieron conplir al dicho termino, el dicho Paredes les avya fecho fazer otra obligaçion a Garçia de Dueñas por çinquenta e nueve mill mrs., según que todo dixo que pareçia por una ynformaçion de que fizo presentaçion e pareçiera mas complidamente en la prosecuçion de la dicha cabsa.

72. ARChV, Registro de Ejecutorias, c. 176, 8; 1503, enero, 31. Antonio de Paredes y otros cambiadores recibían en depósito varias cantidades de dinero que mercaderes como Alonso de la Torre o el burgalés Hernando de Castro reservaban para pagar las costas judiciales de los pleitos en los que estaban inmersos. El alguacil, al proceder al pago de dichas costas, reclamaba al cambiador $1.600 \mathrm{mrs}$. como derechos propios.

73. La presencia de la usura en el género confesional castellano de la primera mitad del siglo XVI denota la excesiva preocupación que fue remitiendo a medida que avanzaba el siglo. Clavero, B.: Antídora. Antropología católica de la economía moderna. Milán, 1991, pp. 111 y ss.

(C) Ediciones Universidad de Salamanca / ®@ Stud. his., H. ${ }^{a}$ mod., 38, n. 1 (2016), pp. 193-222 
Las acusaciones contra el cambiador eran graves ya que suponían un ataque contra su profesionalidad y su honradez, cualidades que cualquier hombre de negocios debía mantener y exhibir en el desarrollo de su actividad ${ }^{74}$. La reacción de Antonio de Paredes no se hizo esperar, afirmando en sus alegatos que todo lo contenido en la acusación era falso y que él era «persona de buena conçiençia, fama, trato e conversaçion e syenpre abya bibido e vibia muy linpiamente en su ofiçio e fuera del no se fallaria aver fecho ni cometido cosa ninguna que no deviese». Finalmente, y tras la apelación del fiscal, la sentencia de revista dejaba libre al cambiador, restituyendo plenamente su honor como financiero ${ }^{75}$, aunque este tipo de desencuentros eran percibidos con gran preocupación en un entorno donde la confianza y el honor de los financieros estaban en cuestión dadas las numerosas quiebras de los cambiadores castellanos a inicios del siglo XvI.

El conjunto de sus negocios, el ingente número de relaciones económicas, su cercanía a la corte, sus relaciones con el concejo vallisoletano y otros atributos ya señalados constituyen elementos suficientes para definir los pilares que nos permiten situar a Antonio de Paredes entre la elite urbana. No obstante, los intereses de un financiero con un enorme capital social, hábil y capaz de actuar en ámbitos muy diversos no culminaron en uno de los objetivos que, aparentemente, compartían muchas de las nuevas elites urbanas: ocupar un puesto de mayor categoría en su villa donde, con toda seguridad, pudo observar el camino emprendido por los miembros de algunas familias, como los Verdesoto o los López de Calatayud en el regimiento. Estas habían logrado hacerse un hueco entre los linajes vallisoletanos y, con ello, acceder al regimiento, con todo lo que esto suponía. A día de hoy no hay constancia de que el cambiador Paredes llegase a ostentar tal puesto. No obstante, ese hecho no le impidió comportarse como un miembro más de la oligarquía vallisoletana ${ }^{76}$. La mejor muestra de ello fue la consecución de uno de sus proyectos más ambiciosos en vida, la construcción de una capilla donde descansarían sus restos y, junto a él, los miembros de una familia llamada a cumplir con sus aspiraciones en la sociedad y en la política local.

Antonio de Paredes parecía tener claro que los negocios de su muerte debían tener tanta trascendencia como los que desarrolló en vida. Su incesante actividad financiera, de la que debió obtener pingües beneficios, y su posición en la villa le permitieron acceder a un espacio reservado para muy pocos. Poco antes de 1512, con unos 45 años y pensando en perpetuar la memoria de su familia, eligió como

74. Carvajal de la Vega, D.: Crédito privado y deuda en Castilla (1480-1521). Tesis doctoral, Universidad de Valladolid, 2013, pp. 379 y ss.; DAvis, J.: Medieval Market Morality. Life, Law and Ethics in the English Markeplace, 1200-1500. Cambridge, 2012, pp. 205-207.

75. ARChV, Registro de Ejecutorias, c. 225, 47; 1508, julio, 31.

76. Kamen, op. cit., p. 95.

(C) Ediciones Universidad de Salamanca / ®@ Stud. his., H. ${ }^{a}$ mod., 38, n. 1 (2016), pp. 193-222 
emplazamiento de su capilla uno de los lugares más representativos de Valladolid y de su elite, el monasterio de San Francisco, situado en la plaza del mercado (o plaza mayor) de Valladolid ${ }^{77}$. Para llevar a cabo la obra que iba a presidir el lugar donde reposaría su cuerpo, un retablo dedicado a Nuestra Señora del Rosario, el cambiador acudió a uno de los más afamados escultores del momento en Castilla, Alejo de Vahía ${ }^{78}$ quien, estando en su taller en Becerril de Campos, aceptó el encargo que realizaría junto a su hijo Copín y a su yerno, Santiago Botas. El retablo que presidía la capilla estaba situado, en palabras de Alejo de Vahía, «en el cuerpo de la yglesia de la dicha San Francisco de Valladolid en el altar frontero del pulpito", y tenía unas dimensiones considerables, "quinçe palmos de alto e onze de ancho», según el maestro y sus ayudantes ${ }^{79}$. Dicho retablo debía quedar encajado en una obra de yesería, realizada por el maestro yesero Francisco Andado-miembro de una reconocida familia morisca ${ }^{80}$, , que destacó por su riqueza decorativa con «sus pilares e chanbranas e corcheles e follajes e en sus cimientos a el coronamiento e escudos de armas e otras cadenas moriscas e otras cosas que tiene la dicha obra todo ello bien fecho e acabado de cochillo» ${ }^{81}$, según la descripción de los maestros yeseros Juan de Palencia y Antonio de Álamos. El minucioso relato de estos dos maestros, encargados de tasar la obra, vino motivado por un pleito entre Antonio de Paredes y los herederos de Francisco Andado, quienes reclamaron al cambiador el pago de la yesería. Al parecer, Antonio de Paredes se había negado a asumir dicho pago puesto que fue necesario destruir parte de la yesería para asentar el retablo y él no estaba dispuesto a hacer frente a un sobrecoste derivado de un error del maestro yesero.

Aunque debió ser a mediados de 1519, desconocemos la fecha de óbito del cambiador, quien al parecer fue enterrado en el lugar citado. Tras los avatares de una intensa vida dedicada a tantas actividades, el ejemplo de Antonio de Paredes es lo suficientemente esclarecedor como para mostrar la perseverancia de un hombre para progresar en el desempeño de sus negocios financieros e integrarse en el seno de la sociedad vallisoletana. Para ello, además de su capital económico, cuidó del social a través de su vínculo matrimonial y de sus relaciones, todo ello reforzado

77. Fernández del Hoyo, M. ${ }^{a}$ A.: Patrimonio perdido. Conventos desaparecidos de Valladolid. Valladolid, 1998, pp. 55 y ss. No cita en ningún momento la existencia de esta capilla, aunque sí sabemos que en sus capillas se enterraron grandes mercaderes y hombres de la villa durante la Edad Moderna.

78. Ara Gil, C. J.: En torno al escultor Alejo de Vabia: 1490-1510. Valladolid, 1974.

79. ARChV, Pleitos Civiles, Pérez Alonso (F), c. 1186, 4.

80. Moratinos García, M. y Villanueva Zubizarreta, O.: «Consecuencias del decreto de conversión al cristianismo de 1502 en la aljama mora de Valladolid», Sharq al-Andalus, 16-17, 1999-2002, pp. 117-139, en especial p. 130.

81. ARChV, Pleitos Civiles, Pérez Alonso (F), c. 1186, 4.

(C) Ediciones Universidad de Salamanca / ®@ Stud. his., H. ${ }^{a}$ mod., 38, n. 1 (2016), pp. 193-222 
por el patrocinio de tan singular enterramiento en el lugar donde importantes mercaderes, como Gómez de Carrión, también estimaron oportuno descansar ${ }^{82}$. No cabe duda del interés que tuvo nuestro personaje por escalar en una sociedad donde las nuevas oligarquías mercantiles y financieras ya ocupaban espacios destacados en la vida pública; al igual que queda claro que los negocios financieros, a pesar de sus riesgos, suponían un trampolín para lograr el tan preciado ascenso. Además, y como colofón a su vida, el cambiador ya había dispuesto todo lo necesario para traspasar a sus hijos el negocio del cambio y dotarles de los medios económicos y del reconocimiento social necesarios para el desempeño de sus actividades y la consolidación de su apellido ${ }^{83}$.

\subsection{Hacia la consolidación de la familia Paredes en Valladolid}

El matrimonio de Antonio de Paredes con Mayor López de Villalón supuso un refuerzo en los vínculos establecidos por la segunda generación de los Paredes en Valladolid. De esta unión nacieron, que sepamos, cinco vástagos cuya influencia en la vida vallisoletana reflejó el notable avance de la familia. Los hijos del cambiador: Juan Fernández de Paredes, el licenciado Paredes (posiblemente Francisco de Paredes ${ }^{84}$ ), Baltasar de Paredes, Gaspar de Paredes y Gómez de Paredes, mantuvieron presente el apellido, tanto en el ámbito de las finanzas y del cambio como entre la elite local. La mayor parte de los Paredes continuaron la actividad de su padre quien, llegando al final de su vida, intentó hacer entrega de importantes sumas de dinero a Juan Fernández de Paredes y a Gaspar de Paredes sin que conozcamos el verdadero motivo de dicha concesión ${ }^{85}$.

Uno de los hijos más conocidos del cambiador, posiblemente su primogénito y uno de los más activos, fue Juan Fernández de Paredes. Su vida representó la consecución del ascenso a la oligarquía local a través del acceso al regimiento. Además de su actividad política como regidor y procurador de la villa en Cortes ${ }^{86}$,

82. AHPV, Protocolos, c. 7840, fols. 438r-441r. En 1519, Gómez de Carrión, mercader vallisoletano, pide que su cuerpo sea enterrado junto a la sepultura del cambiador Antonio de Paredes, en el monasterio de San Francisco.

83. Kamen, op. cit., pp. 14-15.

84. AHPV, Protocolos, c. 7300 , fols. 568r-569v, aparece con su padre como cambiador en Medina del Campo en 1517.

85. A través de una donación que, al parecer, se convirtió en depósito a favor de sus hijos por 380.000 y 200.000 mrs., respectivamente. AHPV, Protocolos, c. 32, fols. 148-150, Valladolid, 1519, septiembre.

86. Aparece como procurador por Valladolid en las Cortes de 1538, Actas de las Cortes de Castilla: http://www.cervantesvirtual.com/bib/historia/CarlosV/7_1_3_cortes1538.shtml (fecha de consulta: 20/01/2014).

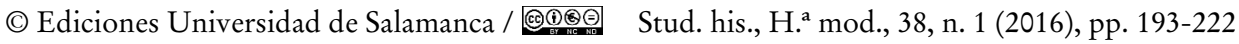


Juan Fernández de Paredes mostró una especial preocupación por la defensa del honor y del patrimonio familiar. En primer lugar, pleiteando por el reconocimiento de su condición de hidalgo ${ }^{87}$, hecho con el que pretendía ver reafirmada su condición de privilegiado, remontándose a los orígenes de sus ancestros en el norte peninsular y al reconocimiento que su abuelo y su padre habían tenido en la villa. Por otro lado, Juan Fernández de Paredes puso empeño en defender sus derechos económicos y los de su familia, litigando con aquellos deudores de su difunto padre que se negaban a cumplir con sus obligaciones ${ }^{88}$. Además de ejercer como cabeza visible de la familia y de mantener esta férrea lucha por sustentar el honor y su patrimonio, el hijo de Antonio de Paredes se hizo cargo de sus propios negocios mercantiles y financieros en torno a las bien conocidas ferias de Medina del Campo y Villalón, donde sabemos que mantenía contactos con agentes llegados de toda Europa (alemanes, italianos, portugueses...) ${ }^{89}$, reproduciendo las prácticas en las que debió instruirle su padre, si bien es cierto que Juan debió lidiar y negociar en un entorno social y financiero mucho más diverso y dinámico del que conoció Antonio. Mientras tanto, en lo que concierne a su vida personal, el regidor contrajo matrimonio con Antonia Corneja, de cuya unión nacieron, al menos, Francisco y Jerónimo de Paredes. Sin ánimo de entrar en mayores consideraciones sobre la cuarta generación, es importante señalar algunos hechos que confirman la consolidación de esta familia entre la oligarquía vallisoletana. Así, valga como ejemplo el traspaso del regimiento en favor de Francisco de Paredes ${ }^{90}$, quien antes había desarrollado una vida profesional vinculada al negocio familiar, actuando como banquero en Medina del Campo en la década de $1550^{91}$. El segundo hijo, Jerónimo de Paredes, también logró un puesto notable como oficial, en este caso como repartidor y receptor de penas en la Real Chancillería ${ }^{92}$. Con sus hijos ocupando puestos de relevancia en la villa, Juan Fernández de Paredes gozaba al final de su vida de una posición acomodada, muriendo en 1558 tras haber contribuido a afianzar el ascenso de la familia.

Otro de los hijos de Antonio de Paredes, Baltasar de Paredes, nos permite seguir defendiendo la integración de la familia en la elite urbana, de nuevo a través de su participación en la política y en el gobierno urbano de Valladolid. Al igual que su hermano Juan, también alcanzó un puesto en el regimiento, ocupación

87. ARChV, Registro de Ejecutorias, c. 660, 7.

88. ARChV, Registro de Ejecutorias, c. 372, 1.

89. ARChV, Pleitos Civiles, Fernando Alonso (F), c. 530,1; Registro de Ejecutorias, c. 729, 57.

90. ARCHV, Registro de Ejecutorias, c. 1053, 8.

91. ARChV, Registro de Ejecutorias, c. 842, 30; 1555, septiembre, 14. Francisco de Paredes reclama $26.500 \mathrm{mrs}$. que restaban de una obligación por un préstamo.

92. DÁvila, V.: Próceres Merideños, Caracas, 1918, p. 103. 
DAVID CARVAJAL DE LA VEGA

CAMBIADORES Y ELITES URBANAS: EL AUGE DE ANTONIO DE PAREDES

Y SU FAMILIA EN VALLADOLID A INICIOS DEL SIGLO XVI

que no le impidió ejercer una provechosa actividad como cambiador. Baltasar residió en un espacio privilegiado de la villa, en unas casas junto al monasterio de San Francisco ${ }^{93}$-donde descansaban los restos de su padre-. La inclusión de los Paredes entre la élite urbana también se hizo evidente a través de su presencia y dominio del espacio urbano. Como su abuelo, su padre y sus hermanos, Baltasar centró sus intereses profesionales en la villa de Medina del Campo, al calor de sus ferias ${ }^{94}$. Su dedicación vino acompañada de acusaciones e infundios que debió soportar, teniendo clara, al igual que ocurrió con su padre, la necesidad de defender su fama y el buen hacer en sus negocios ${ }^{95}$. Durante sus últimos años, el regidor y cambiador también se hizo cargo de otras tareas relevantes ocupando el de tesorero general de la bula de cruzada, puesto para el que su formación como financiero debió ser especialmente útil y adecuada. El regidor compartió buena parte de sus negocios con sus hermanos, Juan Fernández de Paredes ${ }^{96}$ y, sobre todo, con el también cambiador y regidor Gaspar de Paredes ${ }^{97}$. En torno a la década de 1570, Baltasar de Paredes comenzó su retiro, cediendo sus negocios a su hijo y heredero universal, el también cambiador y regidor Felipe de Paredes ${ }^{98}$.

El tercer hijo de Antonio de Paredes, el cambiador Gaspar de Paredes, aparece como uno de los mejores exponentes del apoyo financiero que las oligarquías municipales otorgaron a la política de Carlos I cuando, ya avanzado su reinado, este necesitó recibir por adelantado parte del servicio de cortes obtenido en 1534. Gaspar fue uno de los financieros que acudió al socorro de su majestad adelantando

93. Fernández del Hoyo, M. ${ }^{a}$ A.: «Las casas consistoriales de Valladolid», en Conocer Valladolid 2012. Valladolid, 2013, p. 70.

94. Algunas referencias de sus negocios las encontramos en pleitos como el que mantuvo con el mercader zamorano Francisco de Valencia, a quien reclamaba una deuda pendiente. ARChV, Pleitos Civiles, Alonso Rodríguez (F), c. 443, 3.

95. ARChV, Registro de Ejecutorias, c. 637, 44. La ejecutoria recoge las acusaciones lanzadas contra él y su hermano, el también cambiador Gaspar de Paredes, a quienes se acusaba de usureros por cobrar 12.000 mrs. más sobre una deuda de 162.000 mrs., con lo que habían aplicado un interés del 7,4\%. El pleito finalizó obligando a cumplir el concierto firmado por las partes que, además, debieron mantener más pleitos, ARChV, Registro de Ejecutorias, c. 1008, 63 (1561).

96. Juan Fernández de Paredes y Baltasar de Paredes aparecen como pagadores de Hernando Daza Medina, en este caso debían pagar la dote de Margarita de Espinosa a la abadesa del monasterio de Santa Clara de Medina del Campo, Copia notarial. AMV, Fondo Hospital de Esgueva, caja 405-39. Herrero Jiménez, M. y Díaz Blanco, M. E.: El archivo del mercader Hernando Daza Medina ([1505]-1566). Valladolid, 2009, doc. 364.

97. Era asiduo encontrarlos en Medina del Campo como cambiadores/banqueros, por ejemplo como acreedores conjuntos de Hernando de Cuéllar, contador de la Orden de Calatrava, quien se había obligado a pagar por Francisco de Cazalla, vecino de Logroño, 70.000 mrs. en diciembre de 1538. ARChV, Registro de Ejecutorias, c. 571,52

98. ARChV, Registro de Ejecutorias, c. 1573, 42.

(C) Ediciones Universidad de Salamanca / ®@ Stud. his., H. ${ }^{a}$ mod., 38, n. 1 (2016), pp. 193-222 
DAVID CARVAJAL DE LA VEGA

CAMBIADORES Y ELITES URBANAS: EL AUGE DE ANTONIO DE PAREDES

Y SU FAMILIA EN VALLADOLID A INICIOS DEL SIGLO XVI

la nada desdeñable cantidad de 300.000 mrs. ${ }^{99}$. Además de su cercanía a otros financieros estantes en la Corte ${ }^{100}$, esta significativa operación no dejaba de ser una entre las numerosas transacciones con gentes de toda clase y condición que siguen, en líneas generales, los mismos pasos que las actividades desarrolladas por su padre, hermanos y sobrinos.

Los ejemplos de Juan Fernández de Paredes, Baltasar de Paredes y Gaspar de Paredes son ilustrativos a la hora comprender hasta qué punto los negocios financieros y las estrategias desarrolladas por Antonio de Paredes y sus hijos hicieron posible que los miembros de una familia de cambiadores lograran introducirse en la oligarquía urbana alcanzando incluso el acceso al regimiento y la perpetuación de su posición en él. Aunque poseemos menos referencias de los otros dos hermanos, el licenciado Paredes y Gómez de Paredes, más allá de que mantuvieron su residencia en la villa, sabemos que los descendientes de esta generación siguieron dejando noticias de su vida y de sus actos a lo largo de los siglos que siguen, tanto en la Península como en territorios de ultramar, donde el apellido Paredes quedó vinculado a los próceres que gobernaron ciudades como Mérida ${ }^{101}$.

\section{Conclusiones}

El tránsito del medievo a la modernidad en la Corona de Castilla supuso un momento de cambio a todos los niveles: económico, social, político... y aún más en aquellos centros que, como Valladolid, experimentaron importantes procesos de transformación. El fuerte dinamismo económico impulsó la aparición de nuevos grupos estrechamente vinculados al negocio mercantil y, en el caso planteado, al auge de las finanzas. No sin asumir los peligros derivados de la profesión, hemos tenido ocasión de comprobar cómo determinadas familias, y en particular los miembros de la familia Paredes, aprovecharon las oportunidades de ascenso social que su actividad les proporcionó. La consolidación de algunos negocios en torno al mundo ferial castellano, el cuidado por tratar con todo tipo de mercaderes, oficiales, instituciones... partiendo de su capacidad de proveer capital, permitió a personajes como Antonio de Paredes tener acceso a entornos de gobierno como

99. Carretero Zamora, J. M.: «Fiscalidad extraordinaria y deuda: el destino del servicio de las cortes de Castilla, 1535-1537», Espacio, Tiempo y Forma, Serie IV, $H^{a}$ Moderna, 8, 1995, pp. $11-47$.

100. Al parecer mantuvo una estrecha relación con el cambiador Juan de Portillo con quien hacía de intermediario entre Francisco Verdugo y el cambiador Juan de la Haya, encargado de hacer frente al pago de varios salarios con $130.000 \mathrm{mrs}$. consignados por la Consejo de Indias. Archivo General de Indias, Indiferente, 422, L.17, fol. 4v y 422, L.17, fols. $11 \mathrm{r}$-v.

101. Dávila, V.: Próceres Merideños. Caracas, 1918.

(C) Ediciones Universidad de Salamanca / ®@ Stud. his., H. ${ }^{a}$ mod., 38, n. 1 (2016), pp. 193-222 
la propia Corte, donde ejerció como cambiador, o el concejo vallisoletano. Por ello, más allá de los ejemplos bien conocidos de ascenso social protagonizados por grandes familias de mercaderes o de agentes vinculados casi exclusivamente al negocio de las rentas, podemos afirmar que el cambio, tratándose de la génesis de la actividad bancaria a inicios del siglo xvi, supuso una plataforma desde la que poder prosperar en una sociedad donde la movilidad era creciente.

Además de la consolidación del negocio familiar y de la diversificación de actividades financieras (giro y pago, cambio, depósito, préstamo, recaudación de rentas, tesorería...), es fácil observar cómo algunas familias se preocuparon por desplegar otras estrategias que, en último término, reforzaron su hacienda, además de sus aspiraciones de cara a su integración profesional y a su incorporación a las elites urbanas. Nos referimos a la importancia del matrimonio, a la pertenencia a cofradías de mercaderes y cambiadores o a la preocupación por dejar constancia de la memoria y del apellido a través de un enterramiento singular en un espacio privilegiado.

Como hemos tenido ocasión de comprobar, la bulliciosa villa de Valladolid, uno de los lugares óptimos para que un mercader o financiero se asentase buscando ampliar sus relaciones, se convirtió en un centro accesible donde aspirar a más, en lo económico y en lo social. Es lo que debió pensar Juan de Paredes al llegar desde una pequeña villa al norte del reino y establecer su negocio junto a la puerta del Campo. Desconocemos las pretensiones iniciales de Juan de Paredes, aunque nos atrevemos a afirmar que su hijo, el cambiador Antonio de Paredes, hizo méritos a lo largo de su vida para incorporarse a la elite urbana. No obstante, el progresivo ascenso de cada generación al calor del negocio del cambio, los logros de tres de sus hijos, nombrados regidores en la villa, y la consolidación que supuso la transmisión del regimiento hacia los nietos de Antonio de Paredes (Francisco y Felipe de Paredes) constituyen una evidencia lo suficientemente sólida como para tomar en consideración el ejemplo de esta familia, a pesar de que alguno de sus miembros, en particular, Francisco de Paredes, fuese tachado de «hijo de puta» en las coplas del Provincial Segundo ${ }^{102}$. Al igual que ocurrió con otros grandes financieros de la villa, como los Verdesoto, Antonio de Paredes y sus descendientes encontraron en el cambio y en el negocio financiero un sustento del que nunca renegaron y que no trataron de ocultar, como sí debió ocurrir en otros centros, como Segovia ${ }^{103}$. En definitiva, las finanzas les ayudaron a lograr una posición de

102. Bennassar, B.: Valladolid en el Siglo de Oro. Valladolid, 1989, p. 498. El autor de las coplas era don Diego de Acuña.

103. Mosácula María, F. J.: «Los regidores municipales de Segovia durante los reinados de Felipe II, Felipe III y Felipe IV», Espacio, Tiempo y Forma, Serie IV, $H^{a}$ Moderna, 14, 2001, pp. 245-314, en particular p. 285.

(C) Ediciones Universidad de Salamanca / ®@ Stud. his., H. ${ }^{a}$ mod., 38, n. 1 (2016), pp. 193-222 
DAVID CARVAJAL DE LA VEGA

CAMBIADORES Y ELITES URBANAS: EL AUGE DE ANTONIO DE PAREDES

Y SU FAMILIA EN VALLADOLID A INICIOS DEL SIGLO XVI

enorme influencia en una sociedad y en un territorio ávido de crédito económico y social. A pesar de la visión tradicional de aquellos grandes mercaderes, como los burgaleses, interesados en invertir sus beneficios en la compra de títulos, en la inversión en censos, en la creación de mayorazgos, etc., la realidad se nos antoja más compleja pues, mientras los cambiadores participaron de la dinámica política y socioeconómica de Castilla, se mantuvieron especialmente activos en aquellas actividades financieras que les habían procurado su fortuna y poder. Antonio de Paredes y sus hijos son uno de los numerosos ejemplos de la existencia de familias y de grupos financieros que, conservando su negocio, persiguieron intereses y objetivos acordes a los cambios económicos y sociales de un territorio en plena expansión hasta que, desde la década de 1570 , el proceso quedó truncado ante el descenso de la actividad ferial y el traslado de la corte a Madrid, entre otras muchas causas.

\section{Bibliografía}

Álvarez Bezos, S. y Carreras Zalama, A.: Valladolid en época de los Reyes Católicos según el alarde de 1503. Valladolid, 1998.

ArA GIL, C. J.: En torno al escultor Alejo de Vabia: 1490-1510. Valladolid, 1974.

Bennassar, B.: « Marchands flamands et italiens a Valladolid au Xvie siècle », en KeLLenbenz, H. (hrsg.): Fremde Kaufleute auf der Iberischen Halbinsel. Köllner Kolloquien, 1970, pp. 48-55.

Bennassar, B.: Valladolid en el Siglo de Oro. Valladolid, 1989.

Bonachía Hernando, J. A.: «El encabezamiento de alcabalas de Valladolid (1496-1501). Los sistemas de recaudación», en Bonachía Hernando, J. A. y Carvajal de LA VeGA, D. (eds.): Los negocios del hombre. Comercio y rentas en Castilla. Siglos XV y XVI. Valladolid, 2012, pp. 107-146.

Cañas Gálvez, F. de P.: Burocracia y cancillería en la corte de Juan II de Castilla (14061454). Estudio institucional y prosopográfico. Salamanca, 2013.

Carande, R.: Carlos V y sus banqueros. Barcelona, 1987.

CARLÉ, M. a del C.: «De cambios y cambiadores», Cuadernos de Historia de España, 76, 2000, pp. 121-138.

Carretero Zamora, J. M.: «Fiscalidad extraordinaria y deuda: el destino del servicio de las cortes de Castilla, 1535-1537», Espacio, Tiempo y Forma, Serie IV, Hª Moderna, 8, 1995, pp. 11-47.

Carvajal de la Vega, D. y Bonachía Hernando, J. A.: «Financieros locales en los primeros encabezamientos castellanos: Valladolid, 1496», en Borrero FerNÁNDEZ, M. y Peinado Santaella, R. (eds.): Agentes de los sistemas fiscales en Andalucía y los reinos hispánicos (siglos XIII-XVII). Madrid, 2015, pp. 169-192.

Carvajal de la Vega, D.: «En los precedentes de la banca castellana moderna: cambiadores al norte del Tajo a inicios del siglo XVI», en García Fernández, E. y Bonachía

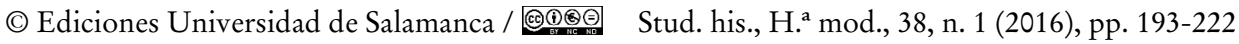


DAVID CARVAJAL DE LA VEGA

CAMBIADORES Y ELITES URBANAS: EL AUGE DE ANTONIO DE PAREDES

Y SU FAMILIA EN VALLADOLID A INICIOS DEL SIGLO XVI

Hernando, J. A. (eds.): Hacienda, mercado y poder al norte de la Corona de Castilla en el tránsito del medievo a la modernidad. Valladolid, 2015, pp. 17-37.

Carvajal de la Vega, D.: Crédito privado y deuda en Castilla (1480-1521). Tesis doctoral, Universidad de Valladolid, 2013.

Casado Alonso, H.: Señores, mercaderes y campesinos: la comarca de Burgos a fines de la Edad Media. Valladolid, 1987.

Clavero, B.: Antídora. Antropología católica de la economía moderna. Milano, 1991.

Collantes de Terán Sánchez, A.: Sevilla en la baja Edad Media. La ciudad y sus hombres. Sevilla, 1977.

Dávila, V.: Próceres Merideños. Caracas, 1918.

Davis, J.: Medieval Market Morality. Life, Law and Ethics in the English Markeplace, 1200-1500. Cambridge University Press, 2012.

Fernández del Hoyo, M. ${ }^{a}$ A.: «Las casas consistoriales de Valladolid», en Conocer Valladolid 2012. Valladolid, 2013.

Fernández del Hoyo, M. ${ }^{a}$ A.: Patrimonio perdido. Conventos desaparecidos de Valladolid. Valladolid, 1998.

García Fernández, E.: «Hombres y mujeres de negocios del País Vasco en la Baja Edad Media», en Bonachía Hernando, J. A. y Carvajal de la Vega, D. (eds.): Los negocios del hombre. Comercio y rentas en Castilla. Siglos XV y XVI. Valladolid, 2012, pp. 107-146.

Guerrero Navarrete, Y.: Organización y Gobierno en Burgos durante el reinado de Enrique IV de Castilla (1453-1476). Madrid, 1986.

Gutiérrez Alonso, A.: «Sociedad y poder. La oligarquía vallisoletana y sus relaciones con otras instancias de poder», en VV. AA.: Valladolid. Historia de una ciudad. Valladolid, 1999, vol. II, p. 383-401.

Herrero Jiménez, M. y Díaz Blanco, M. E.: El archivo del mercader Hernando Daza Medina ([1505]-1566). Valladolid, 2009.

Igual Luis, D.: «Valladolid y sus circuitos económicos en relación (1475-1520)», Edad Media. Revista de Historia, 15, 2014, pp. 104-108.

Jara Fuente, J. A.: «Estructuras formales de poder y de organización de las clases dominantes urbanas en Castilla. El regimiento: una crisis del siglo XIV en el siglo XV», Edad Media. Revista de Historia, 8, 2007, pp. 225-241.

Jara Fuente, J. A.: Concejo, poder y élites. La clase dominante de Cuenca en el siglo XV. Madrid, 2001.

Kamen, H.: Early Modern European Society. Londres, 2000.

Martín Romera, M. a Á.: Las redes sociales de la oligarquía de la villa de Valladolid (14501520). Tesis doctoral, Universidad Complutense de Madrid, 2012

Monguío Becher, F.: Antecedentes de la banca en Jerez de la Frontera. El Gremio de Cambiadores en la segunda mitad del siglo XV. Jerez de la Frontera, 1978.

Moratinos García, M. y Villanueva Zubizarreta, O.: "Consecuencias del decreto de conversión al cristianismo de 1502 en la aljama mora de Valladolid», Sharq al-Andalus, 16-17, 1999-2002, pp. 117-139.

(C) Ediciones Universidad de Salamanca / ®@ Stud. his., H. ${ }^{a}$ mod., 38, n. 1 (2016), pp. 193-222 
DAVID CARVAJAL DE LA VEGA

CAMBIADORES Y ELITES URBANAS: EL AUGE DE ANTONIO DE PAREDES

Y SU FAMILIA EN VALLADOLID A INICIOS DEL SIGLO XVI

Mosácula María, F. J.: «Los regidores municipales de Segovia durante los reinados de Felipe II, Felipe III y Felipe IV», Espacio, Tiempo y Forma, Serie IV, Ha Moderna, 14, 2001, pp. 245-314.

Obra Sierra, J. M.': Catálogo de protocolos notariales: Granada (1505-1515). Tesis Doctoral, Granada, 1986.

Pérez Hernández, S.: «Porque asy conbenia al bien de la dicha villa: cambios políticos en Bilbao (siglos XV-XVII)», en García Fernández, E.: Bilbao, Vitoria y San Sebastián: espacios para mercaderes, clérigos y gobernantes en el Medievo y la Modernidad. Bilbao, 2005, pp. 251-338.

PÉrez, J.: Los judios en España. Madrid, 2005.

Picón-PARra, R.: Fundadores, primeros moradores y familias coloniales de Mérida (15581810). Caracas, 1988.

Pino Rebolledo, F.: El primer libro de actas del ayuntamiento de Valladolid. Año 1497. Valladolid, 1990.

Represa, A.: Libro mayor del «banquero de corte» Ochoa de Salinas (1498-1500). Bilbao, 1980.

Rucquoi, A.: Valladolid en la Edad Media. El mundo abreviado. Valladolid, 1997.

Ruiz Martín, F.: «Las ferias de Castilla», en Lorenzo Sanz, E. (coord.): Historia de Medina del Campo y su Tierra. Valladolid, 1986, vol. II, pp. 269-299.

Soria Mesa, E.: «Los estudios sobre las oligarquías municipales en la Castilla moderna. Un balance en claroscuro", Manuscrits, 18, 2000, pp. 185-197.

Tomás y VAliente, F.: «Origen bajomedieval de la patrimonialización y la enajenación de oficios públicos en Castilla», VV. AA.: Actas del I Symposium de Historia de la Administración. Madrid, 1970, pp. 123-159.

Val Valdivieso, M. ${ }^{a}$ I.: «Medina del Campo en la época de los Reyes Católicos», en Lorenzo SAnz, E. (coord.): Historia de Medina del Campo y su Tierra. Valladolid, 1986, vol. I, pp. 231-314.

VAl VAldivieso, M. ${ }^{a}$ I.: «Valladolid y las villas de su entorno en el tránsito de a Edad Media a la Moderna», en VV. AA., Valladolid. Historia de una ciudad. Valladolid, 1999, Vol. I, pp. 217-242.

Villanueva Morte, C.: «La empresa familiar de los «Litta»: negocios e intereses entre Milán y España desde mediados del siglo XV», Edad Media. Revista de Historia, 10, 2009, pp. 307-341.

VV. AA.: Fundadores, primeros moradores y familias coloniales de Mérida (1558-1810). Caracas, 1988.

Yun Casalilla, B.: Marte contra Minerva. El precio del Imperio español, c. 1450-1600. Barcelona, 2004.

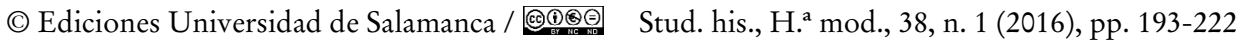

